\title{
Brazilian scientific evidence on Fournier's gangrene
}

\author{
Evidências científicas brasileiras sobre gangrena de Fournier \\ Evidencias científicas brasileñas acerca de la gangrena de Fournier
}

Érick Igor dos Santos ${ }^{1}$, Amanda Luiza Vasconcellos Vertulli Vale², Isabel Cristina Peixoto Marinho dos Reis ${ }^{2}$, Priscila Benevides Neves ${ }^{2}$, Cristiane Marinho Pontes ${ }^{3}$, Sarita Gonçalves de Campos Camara ${ }^{4}$

The objective of this study was to describe the Brazilian scientific reports published over the past twenty years on Fournier's gangrene. It is an integrative review conducted through incursions in the LILACS, MEDLINE, BDENF and Coleciona SUS databases with the descriptor 'Fournier's Gangrene'. Texts published between January 1994 and July 2014, in Portuguese, and freely available online were selected. According to the 14 articles found, the main symptoms of Fournier's gangrene include discomfort with painful sensations, high fever, edema, malaise, and sweating. In most cases erythema and blistering are observed, evolving into a wound. The clinical profile assists in the selection of empirical antimicrobial therapy even before the culture results. It was concluded that early diagnosis and appropriate and aggressive treatment are crucial in patient prognosis. There is still a shortage of Brazilian scientific production with a high power of evidence on the subject.

Descriptors: Fournier Gangrene; Wounds and Injuries; Therapeutics; Review.

Objetivou-se descrever os registros científicos brasileiros publicados nos últimos vinte anos acerca da gangrena de Fournier. Trata-se de uma revisão integrativa realizada por intermédio de incursões nas bases LILACS, MEDLINE, BDENF e Coleciona SUS com o descritor "Gangrena de Fournier". Foram selecionados os textos publicados entre janeiro de 1994 e julho de 2014, em português e disponíveis gratuitamente online. De acordo com os 14 artigos encontrados, os principais sintomas da gangrena de Fournier incluem desconforto com sensações dolorosas, febre elevada, edema, mal estar e sudorese. Na maior parte dos casos são observados eritema e formação de bolhas, evoluindo para uma ferida. O quadro clínico auxilia na seleção da terapêutica antimicrobiana empírica antes mesmo do resultado da cultura. Conclui-se que o diagnóstico precoce e o tratamento adequado e agressivo são determinantes no prognóstico do paciente. Ainda há escassez de produções científicas brasileiras com alto poder de evidência sobre o tema.

Descritores: Gangrena de Fournier; Ferimentos e Lesões; Terapêutica; Revisão.

El objetivo fue describir producciones brasileñas publicadas en los últimos veinte años acerca de la gangrena de Fournier. Revisión integradora realizada en las bases de datos LILACS, MEDLINE, BDENF y Colecciona SUS, con el descriptor "Gangrena de Fournier". Se seleccionaron textos publicados entre enero de 1994 y julio de 2014, en portugués y disponibles gratuitamente en Internet. Según los 14 artículos encontrados, los principales síntomas de la gangrena de Fournier incluyen malestar, con sensaciones dolorosas, fiebre alta, edema, malestar general, sudoración. En la mayor parte de los casos, son observados eritema y formación de bollas, surgiéndose una herida. El cuadro clínico ayuda en la selección de la terapia antimicrobiana empírica antes del resultado de la cultura. En conclusión, el diagnóstico precoz y el tratamiento apropiado y agresivo son cruciales en el pronóstico del paciente. Aún, hay escasez de producciones científicas brasileñas con gran poder de evidencia sobre el tema.

Descriptores: Gangrena de Fournier; Heridas y Traumatismos; Terapéutica; Revisión.

\footnotetext{
${ }^{1}$ Universidade Federal Fluminense. Rio das Ostras, RJ, Brazil.

${ }^{2}$ Centro Universitário Augusto Motta. Rio de Janeiro, RJ, Brazil.

${ }^{3}$ Corpo de Bombeiros do Estado do Rio de Janeiro. Rio de Janeiro, RJ, Brazil.

${ }^{4}$ Fundação de Apoio à Escola Técnica do Estado do Rio de Janeiro. Rio de Janeiro, RJ, Brazil.

Corresponding author: Érick Igor dos Santos

Universidade Federal Fluminense - Departamento de Enfermagem. Rua Recife, s/n, Jd. Bela Vista CEP: 28.890-000 - Rio das Ostras, RJ, Brazil. E-mail: eigoruff@gmail.com
} 


\section{Introduction}

The present study has as theme the lesions concerning Fournier's gangrene. The option for this theme was due to professional and academic experiences of the authors who observed the existence of barriers formed by the lack of knowledge on this type of lesion among health and nursing professionals, besides the difficulty to stablish the early diagnosis. In addition, there is an urgent need to have a better theoretic and scientific basis on Fournier's gangrene based on evidences which can actually contribute for better practices of care made by nurses and other health professionals, as well as for a better understanding of the patients and their family members on this pathology.

It was reported for the first time in 1764 and referred in the literature as a rich synonymy. It received the name Fournier's gangrene as a homage to the French urologist Jean Alfred Fournier, who described it in detail in a work published in 1863, 1864 and 1883 on the cases of scrotal gangrene in young patients apparently healthy. Fournier's gangrene (or Fournier's syndrome) is rare, and has as characteristics the acute start and the progression to sepsis. It especially attacks the genital structures due to bad sanitation of this body topography and/or by the lack of air circulation ${ }^{(1-2)}$.

Fournier's gangrene is also known as necrotizing fasciitis, scrotal gangrene, necrotizing synergistic, synergistic gangrene and fulminant idiopathic gangrene. Besides attacking the perineal genital and anal regions, it can provoke intense odor and subcutaneous emphysema. At this stage the local nervous system can be jeopardized, which provokes the reduction of the pain ${ }^{(2)}$.

This infectious process has the symptoms of fever, early pain and edema. As evolution, it presents necrosis of all the tissue, so its debridement is necessary. This symptom can also be caused due to traumas, loose cell tissue, small infections, low vascularization and thrombosis. Fournier's gangrene attacks both men as well as women, although the prevalence in the male sex is notorious ${ }^{(2-3)}$.

Besides the above mentioned regions, Fournier's gangrene can appear after surgical procedures such as the implantation of penis prosthesis, anal and gynecological procedures, as in the case of orchitis, hydrocele, vasectomy and urinary catechization, besides bladder cancer, epididymitis, and urinary retention, among others ${ }^{(4)}$.

There are other predisposing causes which can be associated to the occurrence of this pathology, such as diabetes mellitus, the age of the patient, lupus, cirrhosis, hemodialysis, malnutrition, radiotherapy, chemotherapy, carcinoma, cortical therapy, alcoholism, renal failure and Acquired Immunodeficiency Syndrome (AIDS). After the case has been confirmed, the immediate treatment must start. It is based on the use of wide spectrum antibiotics and needs to be followed seriously ${ }^{(4)}$.

The treatment of urgency is a surgery with the debridement of the necrotic tissue, even knowing that the process can or not be successful, possibly requiring a new surgical procedure. Even after this procedure it is possible to observe a growing rate of mortality when related to the infection and associated diseases $^{(5)}$.

Considering the above mentioned, the question which guided the present research was: 'Which are the scientific evidences published in the last twenty years on lesions such as Fournier's gangrene?' Its sources were the Brazilian scientific evidences on Fournier's gangrene published in the last twenty years (19942014). And at last, its objective was to describe the Brazilian scientific registers on Fournier's gangrene published in the last twenty years.

\section{Method}

In order to reach the proposed objective, a study of integrative revision of the literature was developed, aiming at integrating the data abstracted from different studies which, in turn, adopted different methodologies, which enables the search, the critical 
evaluation and the synthesis of the available evidences on a specific theme. Six steps inherent to this method were followed; which were: the establishment of the matter of research, the search in the literature, the categorization of the studies, the evaluation of the studies included in the revision, data interpretation of the results and the presentation of the revision ${ }^{(6-7)}$.

This investigation was guided by the following question of research: 'Which are the scientific evidences published in the last twenty years on lesions such as Fournier's gangrene?'

The criteria of inclusion adopted to guide the search and selection of the publishing were: a) Thesis, papers and articles published in national scientific journals revised by peers, who approach the Fournier's gangrene theme in their multiple aspects and contexts; b) Published in the Portuguese language, with the objective to highlight researches which are specifically Brazilian on the theme; c) Published from 1994 to 2014, in order to reflect the scientific evidences inherent to the last twenty years in Brazil; d) Indexed in at least one of the following data basis: Latin-American and Caribbean literature in Sciences of Health (LILACS), Nursing data basis (BDENF), Medical Literature Analysis and Retrieval System Online (MEDLINE) or Coleciona Unified Health System (COLECIONA SUS), which are in the Virtual Library in Health (BVS) or in the Scientific Electronic Library Online (SciELO); e) Placed through the term which is registered in the Portal of Descriptors of the Science of Health: 'Fournier's gangrene'. There was no need of launching others descriptors in other languages besides Portuguese due to its register, codification and unique meaning, dully standardized in the portal of the above mentioned descriptors.

The criteria of exclusion were: a) Publishing which were not available with the complete text (only the abstract); b) Publishing without adherence to the proposed object; c) Publishing that presented availability of the complete text, but whose link presented mistake through the attempt of accessing it.

For the selection of the studies, there was a careful reading of the title and the abstract of each publishing in order to verify the consonance with the guiding question of the investigation. When there was a doubt referring to the inclusion or exclusion of the study, the same was totally read, so that it was possible to reduce the risk of losses of publishing relevant to the study.

The data collection occurred from August 2013 to August 2014, and had the support of a data collection instrument elaborated in the Microsoft Office Excel 2010 software, which had the following variables: Title of the article, journal and year of publication, level of evidence and synthesis of the main results.

The analysis of the data was true to the prerogatives of the integrative revision of the literature. In this sense from the exhaustive reading of the texts, emerged the present evidences of each one of the same.

\section{Results}

The search made in the data basis originated a total of 684 texts, which, when submitted to the criteria of inclusion and exclusion stablished, became only 14. The Latin American and Caribbean Literature in Health Sciences and Medical Literature Analysis and Retrieval System Online data basis revealed the largest number of scientific registers found in 20 years, between 1994 and 2014. However the Latin American and Caribbean Literature in Health Sciences data basis presented the highest number of works after screening based on the criteria of inclusion and exclusion stablished.

The search identified a total of 14 articles, which were published from 2002 to 2012. Five of them were published in 2010, two in 2012 and two in 2011. The years 2002, 2003, 2006, 2007 and 2009 had a draw with just one article published in each one. This result shows the latency of the growth in number of productions on the theme in the last quadrennial. No articles were identified on the theme published in the years 2004, 2005, 2008, 2013 and 2014. 


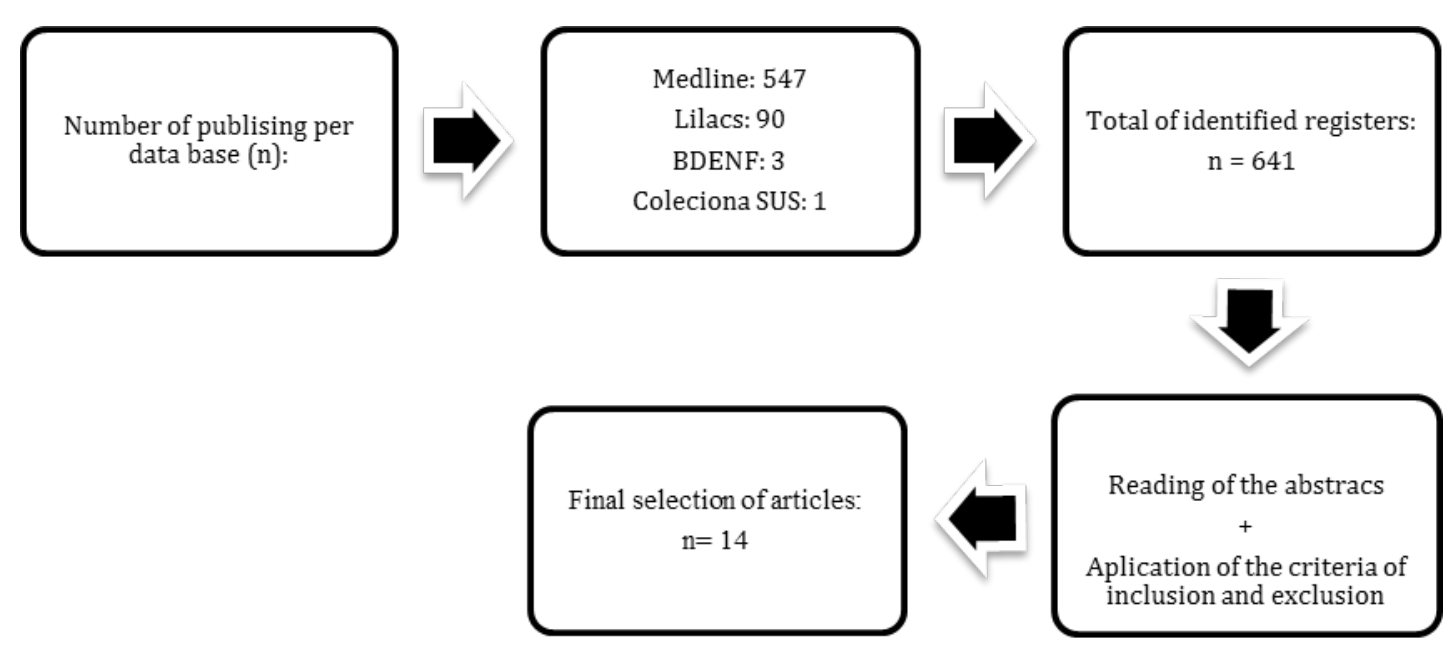

Figure 1 - Flowchart which illustrates the steps for the selection of the studies

Figure 1 shows the steps accomplished in the search and selection of the articles. Furthermore, it also has the distribution of scientific registers per data basis. It is highlighted that, although there have been incursions in diversified bases, there was a very low use of the registers identified in the Medical Literature Analysis and Retrieval System Online. Such characteristic is a limitation of this study.

Figure 2 complements this result. In it, the articles which were found can be observed as well as those selected, based on the established methodological criteria.

\begin{tabular}{|l|c|c|}
\hline Data basis & Found & Selected \\
\hline $\begin{array}{l}\text { Latin American and Caribbean Literature } \\
\text { in Health Sciences }\end{array}$ & 90 & 9 \\
\hline Data Basis of Nursing & 3 & 3 \\
\hline $\begin{array}{l}\text { Medical Literature Analysis and Retrieval } \\
\text { System Online }\end{array}$ & 547 & 1 \\
\hline Collection Unified Health System & 1 & 1 \\
\hline Total & 641 & 14 \\
\hline
\end{tabular}

Figure 2 - Quantitative of the articles found and selected after the integrative revision through a data basis using the descriptor 'Fournier's gangrene'
In turn, Figure 3 and 4 present a synthesis of the variables within the data collection instrument. Each one of the articles received a number from 1 to 14, present in the first of the columns of Figure 4. It is necessary to highlight the low level of evidence ${ }^{(6-7)}$ of most part of the studies identified, which in most cases, obtained a punctuation around 4 and 5 points. This result shows the still modest character, in quantitative terms, of the controlled and experimental clinical studies on Fournier's gangrene published in Brazil in the last twenty years. The quality of the evidences is classified in level 1, for meta-analysis of controlled multiple studies; level 2, individual study with experimental outline; level 3, study with quasi-experimental outline as a study without randomization with pre and post-test only group, time series or control-case; level 4, study with non-experimental outlining as a correlational and qualitative descriptive research as correlational and qualitative descriptive research or case studies; level 5, case or datum report obtained systematically, with verifiable quality or data of evaluation data of programs; level 6, opinion of respectable authorities based on their clinical competence or on the opinion of committees of specialist, including interpretation of information not based on resear$\operatorname{ches}^{(6-7)}$. All the fourteen identified texts were published articles in journals revised by the peers. 


\begin{tabular}{|c|c|l|l|}
\hline № & Year & & \multicolumn{1}{|c|}{ Title } \\
\hline 1 & 2002 & Fournier's syndrome: perception of the bearer & Rev Esc Enferm USP \\
\hline 2 & 2010 & Protocol of an empiric treatment of necrosis infection of skin and face (necrotizing fasciitis) & Medicine \\
\hline 3 & 2003 & Penis scrotal reconstruction after Fournier's syndrome & Arq Catarin Med \\
\hline 4 & 2006 & Perineal abscess caused by accidental ingestions of a tooth pick & Rev Bras Coloproctol \\
\hline 5 & 2007 & Fournier's gangrene & Rev Med Ribeirão Preto \\
\hline 6 & 2009 & Fournier's syndrome: analysis of the factors of mortality & Rev Bras Coloproctol \\
\hline 7 & 2010 & Fournier's gangrene: report of three cases, tomographic findings and revision of the literature & Rev Imagem (Online) \\
\hline 8 & 2010 & Fournier's syndrome secondary to an advanced adenocarcinoma of the prostate: case report & Rev Bras Coloproctol \\
\hline 9 & 2010 & Management of Fournier's gangrene: experience in a university hospital of Curitiba, Brazil & Rev Col Bras Cir \\
\hline 10 & 2011 & Acting of plastic surgery in the treatment of complex wounds & Rev Col Bras Cir \\
\hline 11 & 2011 & Fasciocutaneous flat of internal thigh for scrotal reconstruction in Fournier's syndrome & Rev Bras Cir Plast \\
\hline 12 & 2010 & Fournier's gangrene: retrospective study of 41 cases & Cir Esp \\
\hline 13 & 2012 & Fournier's syndrome: 10 years of evaluation & Rev Bras Cir Plast \\
\hline 14 & 2012 & $\begin{array}{l}\text { Initial experience of the hyperbaric therapy in Fournier's syndrome in a reference hospital in } \\
\text { the south of Santa Catarina state, Brazil }\end{array}$ & Arq Catarin Med \\
\hline
\end{tabular}

Figure 3 - Distributions of the articles by numbers, year of publishing, title and journal in which they are published

\begin{tabular}{|c|c|c|}
\hline № & Results & $\begin{array}{r}\text { Level of } \\
\text { evidence }\end{array}$ \\
\hline 1 & There can be pain, edema and fever, generating physical, economical and family problems & 4 \\
\hline 2 & The hyperbaric oxygen therapy showed to be effective in cases of gangrene caused by Clostridium & 6 \\
\hline 3 & Reports the case of a patient with lesion attacking the scrotum and penis due to Fournier's gangrene & 4 \\
\hline 4 & $\begin{array}{l}\text { The perineal abscess can progress into Fournier's gangrene. The approach must be aggressive with drainage and } \\
\text { removal of foreign bodies }\end{array}$ & 4 \\
\hline 5 & It is a polymicrobial infection which evolves to fasciitis & 6 \\
\hline 6 & The mortality rate is related to the dissemination of the infection & 4 \\
\hline 7 & $\begin{array}{l}\text { Fournier's gangrene requires early diagnosis, and immediate clinical or surgical treatment. The computerized } \\
\text { tomography can be used to the diagnosis }\end{array}$ & 4 \\
\hline 8 & The advanced adenocarcinoma of prostate must be remembered as one of the etiologies of Fournier's syndrome & 4 \\
\hline 9 & $\begin{array}{l}\text { The most prevalent etiological agent was Escherichia coli. The diabetes mellitus can be a risk factor. The most used } \\
\text { antibiotic therapy was metronidazole and gentamicin }\end{array}$ & 5 \\
\hline 10 & It reports the action of the plastic surgery in the treatment of complex wounds, including Fournier's gangrene & 5 \\
\hline 11 & The fasciocutaneous flap in the internal region of the thigh is safe and presents a positive static result & 4 \\
\hline 12 & It is the report of a case of a patient with Fournier's gangrene and diagnosis of advanced prostate adenocarcinoma & 5 \\
\hline 13 & Early debridement, antibiotic therapy of a wide-spectrum and multidisciplinary approach are important therapeutic & 5 \\
\hline 14 & $\begin{array}{l}\text { The most frequently found etiological agent was Enterobacter agglomerans. The average time of hospitalization was } \\
45 \text { days }\end{array}$ & 5 \\
\hline
\end{tabular}

Figure 4 - Synthesis of main results and level of evidence of each article selected 


\section{Discussion}

Fournier's gangrene was first described by Hippocrates in the fifteenth century b.C, as a complication of erysipelas. Fournier's gangrene is a synergic necrotizing fasciitis of the perineum and of the abdominal wall, which has its origin the scrotum and in the penis, in the case of men, and in the vulva and groin, in the case of women ${ }^{(8-19)}$. The causes of Fournier's gangrene can also be associated to cuts, burns, abrasions, lacerations, contusions, animal bites, insect bites and subcutaneous and intravenous injections.

Fournier's gangrene is considered a disease of extreme gravity once it is frequently associated to toxicity and presents a rapid evolution. That is why, it is important that the nurse or another health professional has the knowledge of bacteria involved in Fournier's gangrene, once this, associated to the global evaluation of the clinical picture, helps in the selection of the empiric anti-microbial therapeutics even before the results of the cultures. Therefore the early diagnosis and the aggressive and adequate treatment are determining factors of the prognosis of the patient ${ }^{(8,13,20)}$.

As the dissemination of aerobic and anaerobic bacteria occurs, the concentration of oxygen in the tissues is reduced. With the hypoxia and ischemia tissue, metabolism is impaired, causing further spread of facultative microorganism which benefits from the energy sources of cells, especially in the early 48 to 72 hours of infection.

The most important aspect in the management of the patient with Fournier's gangrene is the early diagnosis and treatment ${ }^{(11)}$. The health professional who provides the first assistance must do it in a thoroughly, thus avoiding the risk to have a wrong diagnosis. Image exams such as the computerized tomography can be useful in the diagnosis of Fournier's gangrene ${ }^{(14)}$. Because of the urgency of the early diagnosis of this type of infection, it is suggested to have a joint evaluation of the multidisciplinary team, especially the one made by the stoma therapist nurse, both for being an extensive wound, dangerous to life, as well as for having the potential to justify the confection of a stomach - both are areas of expertise of that health professional. It is necessary to highlight that once, it usually attacks the urogenital topography of the patient, the confection of eliminations stomas must be necessary.

The synergic action of aerobic and anaerobic bacteria can be responsible for the frequent and fulminant evolution of the disease ${ }^{(16,21)}$. The quantitative and the types of microorganisms involved in Fournier's gangrene will be intimately related to the site of the infection, especially if it is on the abdominal wall, extremities and perineal. The most common Gram-negative microorganisms found in lesions of this type are Escherichia coli, Klebsiella pneumoniae, Pseudomonas aeruginosa and Proteus mirabilis. Among the Gram-positive aerobics the Staphylococcus aureus, Staphylococcus epidermidis, Streptococcus viridans and Streptococcus fecalis are highlighted ${ }^{(13)}$. Metronidazole and gentamicin antibiotics of choice are the pharmacological treatment of such infection ${ }^{(2)}$.

Concerning the signs and symptoms, discomfort can be felt with painful sensations, high fever, and malaise and sweating. An edema apparently without lesion can also be observed. But, in most of the cases, erythema and blistering are observed, evolving to a wound ${ }^{(2)}$. The nurse can make a detailed and periodical examination of the skin in order to verify such alterations.

Despite all the current therapeutic advances, Fournier's gangrene is still presenting high rate of mortality. Death can occur in patients with prolonged disease, dissemination of the infection and impairment of the lungs, which can be foreseen through the clinical assistance and evidences of septicemia ${ }^{(5)}$. The early recognition of the infection associated to an aggressive and invasive treatment are essential measures to decrease those cases. As to the quality of life, the skin grafting or fasciocutaneous flap are satisfactory alternatives $^{(9,13,16) \text {. }}$ 
The clinical and surgical treatment must be immediate, with the use of broad-spectrum, covering Gram-positive and Gram-negative microorganisms. The surgical procedure is indispensable, including hyperbaric oxygen therapy and the medium chain triglycerides such as sunflower oil as complementary therapies. As adjuvant measure, the nutritional support is also indicated. Besides that, the use of hormones of the growth, which have the potency to promote a faster healing of the wound, have also been useful. It is also mentioned the use of papain, which helps in the debridement, attacks infection and accelerates healing, depending on its concentration ${ }^{(22-25)}$. As to the treatment with hyperbaric oxygen therapy, the results have been controversial, once some authors defend its use while others state that there is the need of more studies when it is applied on the several types of fasciitis $^{(9,11)}$.

It is understood that pain deserves special attention during the completion of dressing or other movements of the body of the patient, even if analgesia can be present during the performance of procedure at the site.

As one of the most relevant results, a study identified the lack of orientation from the caregivers to the patients on the causes and preventive measures of Fournier's gangrene. So, it is evident that there is the need that the caregivers, whether they are health professionals or not, are better trained in the cognitive, psychomotor and affectional aspects, so that they can promote a more professional and/or human assistance $^{(8)}$.

\section{Conclusion}

Fournier's gangrene is a theme which is little debated in the scope of health in the last twenty years, especially in the areas of nursing. However, the patient still suffer due to the need of long periods of hospitalization, being subject to several complications which could be minimized. So, it is urgent to have new initiatives of investigation with high power of evidence on the theme, once articles were identified in this revision, mostly in level 4 or below. This revision showed the scientific trends on Fournier's gangrene according to the articles published in the last twenty years on the theme. It is suggested to make more clinical and experimental studies on Fournier's gangrene.

It is concluded that Fournier's gangrene can unleash several complications such as trauma of urethra, rupture of the bladder and increase of its gravity, the latter influenced by the age of the patient, when it is advanced.

An early diagnosis, the adequate treatment and the assistance of nursing with precise interventions are important. Although the daily examination of evolution of the wound is necessary, all the nursing team must have full knowledge of the pathology, otherwise, it will not be possible to identify the signs of complications of the disease. The periodical assistance with a stoma therapeutic nurse is recommended for the register of the clinical evolution of the pathology and specialized assistance to the patients with the loss of cutaneous integrity.

Because this disease is mutilating and promotes problems of self-image, it results in a feeling of insecurity, fear and loss, it is fundamentally important to have the assistance of the nursing team to the patient, clarifying doubts, leading the patient to trust in the team and in the treatment, in order to have a better preparation to cope with it.

This integrative revision, despite the limitations imposed by the high specificity of the criteria of inclusion and exclusion of the study, as well as by the small number of productions identified, allowed to notice the scarcity of studies on Fournier's gangrene in Brazil in the last two decades. It is a function of the health professionals to promote preventive actions and early outline plans of care in cases of Fournier's gangrene. 


\section{Collaborations}

Santos ÉI, Vale ALVV, Reis ICPM, Neves PB, Pontes CM and Camara SGC reported to have participated in the steps of writing of the manuscript, from the elaboration of the Project of research to the final writing and its submission to the journal.

\section{References}

1. Godoy CB, Cassitas MF. A síndrome de Fournier. Rev Med Res. 2014; 16(1):49-50.

2. Mehl AA, Filho DCN, Mantovi LM, Grippa MM, Berger R, Krauss D, et al. Manejo da gangrena de Fournier: experiência de um hospital universitário de Curitiba. Rev Col Bras Cir. 2010; 37(6):435-41.

3. Barreda JT, Scheiding MM, Fernández CS, Campaña JMC, Aguilera JR, Miranda EF, et al. Gangrena de Fournier: estudio retrospectivo de 41 casos. Cir Esp. 2010; 87(4):218-23.

4. Raya-Cruz M, Ferullo I, Arrizabalaga-Asenjo M, Nadal-Nadal A, Díaz-Antolín MP, GarauColom $\mathrm{M}$, et al. Infecciones de piel y partes blandas en pacientes hospitalizados: factores epidemiológicos, microbiológicos, clínicos y prognósticos. Enferm Infecc Microbiol Clin. 2014; 32(3):152-9.

5. Candelaria PAP, Klug WA, Capelhuchnik P, Fang CB. Síndrome de Fournier: análise dos fatores de mortalidade. Rev Bras Coloproctol. 2009; 29(2):197-202.

6. Santos ÉI. Skin tear treatment and prevention by nurses: an integrative literature review. Rev Gaúcha Enferm. 2014; 35(2):142-9.

7. Dias CA, Borges, EL. Recomendações para prevenção e tratamento de lesões de pele decorrentes de epidermólises bolhosas. Rev Enf Atual Derme. 2013; 13(66):8-15.

8. Cavalini F, Moriva TM, Pelei NTR. Síndrome de Fournier: a percepção do seu portador. Rev Esc Enferm USP. 2002; 36(2):108-14.

9. Manso GA, Iniesta RS, Méndez MLS. Protocolo de tratamento empírico de las infecciones necrosantes de piel y fascia (fascitis necrosantes). Medicine. 2010; 10(51):3451-5.
10. Rey SD, Ayub FRJ, Balderrama CMSR, Mima CE, Muniz LP, Nigro MVAS, et al. Reconstrução penoescrotal após Síndrome de Fournier. Arq Catarin Med. 2003; 32(supl.1):268-72.

11. Coltro PS, Ferreira MC, Batista BPSN, Nakamoto HA, Milcheski DA, Tuma JP. Atuação da cirurgia plástica no tratamento de feridas complexas. Rev Col Bras Cir. 2011; 38(6):381-6.

12. Lopes RI, Sant'anna AC, Dias AR, Lopes RN, Barbosa FCM. Abscesso perineal por ingestão acidental de palito de dente. Rev Bras Coloproctol. 2006; 26(2):193-6.

13. Cardoso JB, Féres O. Gangrena de Fournier. Rev Med Ribeirão Preto. 2007;40(4):493-9.

14. Judice PLP, Christofoli MOJM, Oliveira PCR, Teles IG, Naijar YSJ. Gangrena de Fournier: relato de três casos, achados tomográficos e revisão da literatura. Rev Imagem. 2010; 32(1/2):21-3.

15. Batista RR, Filho PRR, Castro CAT, Fonseca MFM, Albuquerque IC, Formiga GJS. Síndrome de Fournier secundária a adenocarcinoma de próstata avançado: Relato de Caso. Rev Bras Coloproctol. 2010; 30(2):228-31.

16. Mauro V. Retalho fasciocutâneo de região interna da coxa para reconstrução escrotal na síndrome de Fournier. Rev Bras Cir Plást. 2011; 26(4):707-9.

17. Sánchez LMV, Maldonado SIC, Rincón JCG, Cadena MCR. Infección necrosante de tejidos blandos y neoplasia gastrointestinal. Infectio. 2014; 18(1):28-33.

18. Dornellas MT, Correa MPD, Barra FML, Corrêa LD, Silva EC, Dornelas GV, et al. Síndrome de Fournier: 10 anos de avaliação. Rev Bras Cir Plást. 2012; 27(4):600-4.

19. Rocha ST, Filho JBC, Petry MS, Bernardi RM, Bueno GB, Warmling CZ. Experiência inicial da terapia hiperbárica na síndrome de Fournier em um hospital de referência no sul catarinense. Arq Catarin Med. 2012; 41(4):71-6.

20. Azolas RM. Factores de riesgo para mortalidad en gangrena de Fournier. Rev Chil Cir. 2011; 63(3):270-5. 
21. Valdés EF, Roca NA,Andrade JK, CunhaYF. Gangrena de Fournier. Rev Cubana Cir. 2013;52(2):91-100.

22. Jiménez-Pacheco A, Arrabal-Polo MA, AriasSantiago S, Arrabal-Martín M, Nogueras-Ocaña M, Zuluaga-Gómez A. Fournier Gangrene: Description of 37 Cases and Analysis of Associated Health Care Costs. Acta Dermosifiliogr. 2012; 103(1):29-35.

23. Firmino F, Alcântara LFFL. Nurses in the provision of outpatient care for women with malignant fungating wounds in the breasts. Rev Rene. 2014; 15(2):298-307.
24. Milcheski DA, Zampieri FMC, Castro FM, Nakamoto HA, Júnior PT, Ferreira MC. Terapia por pressão negativa na ferida traumática complexa do períneo. Rev Col Bras Cir. 2013; 40(4):312-17.

25. Domínguez LP, Rivera HP, Alvarado NC, Saco AL, Vázquez AR, Núñez EC. Vacuum assisted closure: utilidad en el abdomen aberto y cierre diferido - experiencia en 23 pacientes. Cir Esp. 2012; 90(8):506-12. 